\title{
The "Wooden Substitute" in Graham Swift's The Son, or the Further Step in the De-familiarizing Transition from Modernism to Postmodernism"
}

\author{
Juan Jesús Aguilar Osuna \\ juanj_aguilar@hotmail.com
}

\begin{abstract}
Graham Swift, as a postmodernist writer, partakes of the ontological defamiliarizing spirit that has become "the dominant" in the literature of the second half of the twentieth century. His short story The Son is a micro-scale version of the way in which he -by exploring problematic family bonds, most of them non-biological parent-child correspondences- literally de-familiarizes in his longer works the artificiality of the referential relationship that is assumed to exist between a supposedly objective reality and man's representation/creation of it. In this way, translating family relationships into referential bonds between signs and their referents, The Son can be approached as an allegorical dramatization of a further development in the consciousness of defamiliarization that helps to trace a transitional movement from modernism to postmodernism. This awareness of the hiatus in referential bonds and of its further implications may not be pleasant for everybody, but it is definitely liberating.
\end{abstract}

One of Viktor Shklovsky's main contributions to Russian Formalist theory was his seminal concept of ostranenie, or "make it strange." He employs it to express his understanding of literature as a collection of stylistic and formal devices that writers have at their disposal to present old or commonplace ideas in a new and defamiliarizing manner. This process of defamiliarization of the usual is for Shklovsky "a timeless aesthetic universal" (Hodgson, 1985: 197), which, to a greater or lesser degree, is present in any literary text (in fact, this 
is one of the features that makes a text distinctively literary (Holquist, 1985: 87)), and in no way is it exclusive to contemporary postmodern works. Defamiliarization is a feature of all literary texts, while it is incongruity and a lack of proportion that is more typical of contemporary narratives. The Novel, as an antitraditional and continually evolving genre, has been always displaying a progressive undermining of the fact that artificiality is at its roots. However, it is not until the appearance of some contemporary postmodernist texts that a further and more consciously insistent stage in the defamiliarization of the literary process and, by extension, of the ways in which we perceive reality, is reached.

Graham Swift is often referred to as a postmodernist writer, though his novels and short stories are ostensibly not as experimental as those written by other contemporary novelists (such as Peter Ackroyd, Christine Brooke-Rose, Alasdair Gray, etc.). However, upon closer examination it is clear that Swift partakes of the ontological defamiliarizing spirit that has become "the dominant" ("the focusing component of a work of art ... [that] rules, determines, and transforms the remaining components" (Jakobson, 1971: 105)) in the literature of the second half of the twentieth century. "The Son", one of the short pieces in the collection Learning to Swim and Other Stories (1982), exemplifies the way Swift, in his longer works, literally de-familiarizes the artificiality of the referential relationship that is assumed to exist between a supposedly objective reality and man's representation/creation of it. In most of his works, he thematizes this representational gap between sign and referent, between language and reality, by presenting characters with problematic family bonds, most of them having to do with non-biological parent-child correspondences. ${ }^{1}$ This motif recurs with certain variations. Thus, it is not unusual to find sons that in the end are not so: Dick in Waterland (1983), Bill Unwin in Ever After (1992), and Vince in Last Orders (1996). There are also several instances of barren women, who prevent continuity in history: the narrator's wife in "Seraglio", Mary Metcalf in Waterland, and Anna Alexopoulos in "The Son." Finally, there are also some characters that are physically maimed, or, in other words, may be considered fake descendants: Nail in "Cliffedge", Dick in Waterland and June in Last Orders.

The Son is a paradigmatic story that explains and justifies these peculiar family relationships in which Swift seems to be so interested. Furthermore, this short piece can be understood as the allegorical dramatization of a development in the consciousness of defamiliarization of the processes underlying man's construction of reality. This evolution in awareness, among other circumstances, highlights the existence of a transition from modernism to postmodernism as a stage in the development of the Novel as genre. At this point, a consideration of some critics' views on the meaning, limits, and implications of both these terms would be appropriate. Brian McHale points out that "the referent of 'postmodernism,' the thing to which the term claims to refer, does not exist", in the same manner that "'the Renaissance' or 'romanticism' do not exist." For him, all these labels are "discursive constructs" or "artifacts" (pp. 4-5). In Ihab Hassan's view, as categorical terms, these markers suffer "from a certain semantic instability", and, as far as modernism and postmodernism are regarded, they are not "separated by an Iron Curtain or Chinese Wall" (pp. 87-88), something that also happens with modernism and Victorian literature, and with 
any literary period and those which precede and succeed it. In order to distinguish modernism from postmodernism critics usually present catalogues of features arranged in oppositional relationships (see Lodge, 1977: 220-245; Hassan, 1987: 84-96; and Fokkema, 1984), although both movements are not necessarily opposed to one another in any fundamental way. On the contrary, postmodernism can be understood as a poetics which is "the successor of", apart from being "a reaction against, the poetics of early twentiethcentury modernism" (McHale, 1987: 5). Linda Hutcheon (1988: 43) also supports this opinion when she says that "the postmodern clearly... developed out of other modernist strategies: its self-reflexive experimentation, its ironic ambiguities, and its contestations of classic realist representation."

All these views question, on the one hand, the validity of the labels "modernism" and "postmodernism" as categorical terms (since they unavoidably tend to simplification) and, on the other the fact that a clear-cut distinction can be made between the two literary movements these tags purport to refer to. While all this is true, these critics go on using both labels in order to establish certain tensions, differences, and similarities that can be found between works written at the beginning and in the second half of this century. Within the wide range of meanings and connotations assigned to and conveyed by these terms while encompassing different disciplines, my purpose here is to focus on the aspect of defamiliarization in order to examine the way in which, while there are many instances of defamiliarizing devices and techniques in modernism, there is a growing consciousness of these processes and of their implications in postmodernism. In this way, "concepts of Postmodernism can be viewed as uncovering a dimension within Modernism which has been buried for some time. Postmodernism makes visible a sort of reduced rationalism to which we have been blinded by the light of Modernism" (Lethen, 1986: 232).

Being at some points a logical development of some modernist claims, one of the purposes of postmodernist fiction is that of problematizing the entire activity of reference, proposing that referents are fictive and artificially constructed. As Hutcheon (1988: 147) puts it, "what defines reference is not empirical existence ... but a set of internally consistent criteria which constitute the truth-conditions of a discourse." Far from completing the further attempt of modernism to fulfill the liberating Enlightenment "project on absolute knowledge" (Ferraris, 1992: 19), postmodernism finds that liberation in accepting the fictional character of the ontologies man improvises, of the possible worlds he erects according to his interpretations of what is understood by reality. Whereas modernism, as McHale (1987) proposes, has epistemological concerns ("What is there to be known? ... How do they know it, and with what degree of certainty?", p. 9) as its "dominant", postmodernism turns to ontological ones ("What is the mode of existence of a text, and ... of the world (or worlds) it projects?", p. 10).

As stated above, The Son can be approached as an allegory of the growing postmodern consciousness of defamiliarization of the processes by means of which man constructs reality. To carry out this reading in which "defamiliarization" encompasses the connotation of de-familiarization, family relationships must be translated into referential bonds that work as nexuses between signs and referents. ${ }^{2}$ Thus, in the case of Swift's work, sons will 
work as meaningful signs as long as they have fathers that function as those referents onto which they project themselves to become descendants. Fathers, in their turn, will also be signs that, in order to become meaningful, point towards their sons as their referents.

These are, however, instances of unproblematic relationships, represented neither in Swift's story nor in postmodernism, nor in the work of post-structuralist critics such as Roland Barthes and Jacques Derrida. Modernists already realized the weak line that relates sign and referent, man's representation of reality and reality itself, but they tried to cover that gap at the core of that representational system by retrieving or devising mythical patterns that kept them anchored in a past that they could understand as their origin, as the cause that conveyed their fragmented present with the character of an ordered, teleological, and consequential outcome. Joyce, Eliot, and Yeats immediately come to mind. Nevertheless, as Alan Wilde (1992: 16) explains, in postmodernism "[t]he modernist nostalgia over origins is replaced by a dismissal of them: the frustration of being unable to resolve a dilemma gives way to an acceptance of the impossibility of making any sense whatever of the world as a whole." As this critic goes on to say, "[a]cceptance is the key word here", but this acceptance is not always smooth and pleasant. On the contrary, in The Son Swift proposes through the development of his characters' lives that the transition to, as well as the implication in the contemporary postmodern condition can be painful, most of all for those who have always been living according to apparently well-established (even if unavoidably artificial) modernist patterns of origin. As it happens in Swift's larger works, most obviously in Waterland, the initially uncomfortable transitional process from a modernist to a postmodernist way of thinking eventually becomes a liberating alternative that allows his characters to carry out a rewriting, a recomposition, of their fragmented selves, by rejecting "the very basis of modernist beliefs", that is to say "[d]istance, detachment, depth, essentialism, anthropomorphism, humanism, analogies, and the privileging of sight" (Waugh, 1984: 16).

The two main characters in The Son are Kosta Alexopoulos, a Greek immigrant and owner of a restaurant in England, and his adopted son, Adoni. Kosta is the character through whom the increasing consciousness of de-familiarization will be displayed, and, therefore, may be considered the main focus of this study. He appears as the homodiegetic narrator-focalizer through whom we see the action, and his main concern is the fact that he has never told Adoni (who by now is thirty-five) that he is not really his son, or that he, Kosta, is not his biological father. Kosta cannot help being aware of the gap that exists in the artificial kind of father-son relationship between them, a non-existent kinship that introduces the subject of de-familiarization at a thematic level from the very beginning. Translating this situation into referential terms (as I will continually be doing throughout this study) Kosta thinks that, as opposed to innocent Adoni, he has a privileged knowledge of something that has always existed, namely the void between both of them as signs of and referents for each other. His way of coping with this discontinuity in a supposedly familiar and historical line has been by concealing it, thus avoiding the acknowledgment of its existence. As he says: "We even began to kid ourselves: He really is ours; he isn't anybody else's" (p. 127). However, he is constantly afraid that maybe some day he will feel 
compelled to reveal and face up to the consequences of this gap, which will definitely break the illusion of continuity that helps him develop as an uninterrupted line in time and that gives his existence a historical meaning and dimension.

There is still an important difference between Kosta and Adoni. The revelation of the breach in their family bond would leave Adoni as a single point lost (in a figurative manner) in space and time, without any origin that can provide a meaningful sense and orientation to the development of his life. It would mean a complete de-familiarization of his existence. On the contrary, Kosta would lose continuity but not his origin, since he knows, or at least thinks, that he is strongly anchored in a solid past that he is constantly bringing to mind. The opening paragraph is, in fact, a painful remembrance of that time when he was only a boy in World War II and he cut off some of his mother's fingers in order to get the "three fat rings" off them, "rings to barter for food" (p. 124). Taking this difference into account, the reader can interpret Adoni's case as that of a postmodern character, of a Derridean signifier that has no real traceable signified but himself. Kosta's, in contrast, is that of a modernist character who lives in a fragmented present and uncertain future, but who can still resort to a past where he can find patterns and connections (transcendental signifieds) which order his current experience. Kosta knows that, in a sense, both of them are simulacra (Adoni of a son, he of a father); but, as a modernist driven by epistemological concerns of knowledge and its certainty, he trusts that he is not a complete simulacrum, for he knows that a solid referential relationship has always been established between him and his parents.

The story opens with Kosta's (post)modernist Einsteinian consciousness of relativity: "It's true: everything changes. What you think you know, you don't know. What's good or bad at one time isn't good or bad at another" (p. 124). It seems that he is worried about Adoni's situation and conscious of the disorientation and pain that the young man can suffer if he learns the truth about his parentage. This preoccupation about things that you think you know but that you do not actually know makes Kosta think about the possible leaks in referential relationships that other people and things may also suffer. He begins to suspect that the borderline between certainty and appearances is not, or might not be, so well defined. In a world ruled by a generalized uncertainty of which we are unaware most of the time (as it is, or at least seems to be, the case of Adoni) Kosta is concerned about the fact that people might not be themselves, concrete and independent entities, but always like somebody or something else (p. 127). Everybody exists in comparison, and not only in a paradigmatic but also in a syntagmatic relationship, with somebody or something else. This leads to the uncomfortable acknowledgment of a discontinuity in the relationship between sign and referent that defamiliarizes their supposedly direct and solid correspondence, which is displayed as constantly postponed, deferred in a Derridean way, and finally unrecoverable.

This growing awareness begins when Kosta considers Adoni's situation. He comments on the lack of relationship between the name Adoni was given (Adonis is the Greek god of beauty and fertility) and his actual physical aspect: "[E]ven in appearance this Adonis is a rebel to his name. His flesh is pale and pasty; at thirty-five he has the thick build of a man twenty years older" (p. 127). In a desperate but hopeful modernist attempt to suit the name 
to its bearer so that a curtain can also be drawn on this hiatus in a literal sign-referent connection, Kosta hires pretty waitresses for the restaurant they own so as to offer Adoni the possibility of becoming a real Adonis, at least in some sense. "Live up to your name", he thinks. "Take her up to your room and screw her for your Mama's and Father's sake" (p. 129). This never happens, but, on the contrary, the lack of correspondence between sign and referent is aggravated when it does not appear only with regard to Adoni's name. Thus, for example, although he helps his parents with the restaurant, "[in] the evenings, he doesn't prance and scurry like a waiter should; he lumbers between the tables like a great bear" (p. 127; my emphasis here and in subsequent appropriate occurrences of this word). Finally, he is only like a son, no more than a "wooden substitute" (p. 130), which leads Kosta to exclaim desperately: "This son of mine -he wasn't a man, he wasn't a Greek; he wasn't anything" (p. 130). Note, however, Swift's irony in the persistent trick of self-delusion in Kosta's sentence, for Adoni is a man and a Greek, but not his son.

This character of simulacrum is not only reduced to Adoni, but it extends to other people in the story. Lately, Adoni has begun going to the "Neo Elleniko", a club, as Kosta explains, "for so-called expatriate Greeks", although "two thirds of them aren't Greeks at all. They are crazy Cypriots" (p. 131). Nevertheless, in spite of his despising tone, Kosta is not exactly Greek himself, since he was born in Smyrna in Asia Minor (p. 125). Moreover, he acknowledges that he himself speaks with his customers "like a proud Greek restaurant owner should" (p. 127), and says: "I never fail to play my part and give a twinkle to my eyes. We Greeks are like that: We come alive, we perform, like drooping flowers splashed with water" (p. 128). He is conscious that he is not a real restaurant owner by vocation (p. 125), for he only plays a role, as if he were an actor in a Greek tragedy. However, he is more afraid of facing the fact that he is a "wooden father", in the same way that Adoni is a "wooden son."

Kosta suspects that Adoni is becoming interested in his own past, in his origins as a Greek, which for Kosta means that he is "trying to get at the truth" (p. 131). This is what has led the young man to go to the library and read books with titles such as "Mysteries of the Past" or "The Secret of Mind-Power" (p. 128), and to pay frequent visits to the Neo Elleniko. Kosta is afraid that any of "those old fogies" (p. 131) at the club might know something about the Alexopoulos's and Adoni's real past, and one day his suspicions are confirmed, for all of a sudden Adoni tells them he wants to go to Greece for the holidays he had never taken before. When Kosta picks him up at the airport upon his return, he can see that Adoni already knows the truth: "I can't kid myself any more he's a son of mine" (p. 133). Once in the restaurant Adoni tells him that he knows the truth, that a certain Elias Tsobanidis has told him that his real name is not Alexopoulos but Melianos. Now Adoni is consciously postmodern, for he has been forced to dismiss any kind of nostalgia for his origins, for any transcendental signified. Kosta, in his turn, sees that the artificiality of their father-son relationship that he was concealing has been finally undermined and is, therefore, disintegrating. But Adoni brings some more information, as he tells him: "Elias told me something else too... . He said your name is not Alexopoulos either" (p. 135). The effect of this last drastic and literal de-familiarization is that of suddenly sending Kosta from the 
modernist to the postmodernist side. Whereas he saw Adoni's disintegration from a relatively safe distance, now he finds himself completely implicated in a situation parallel to that of his "wooden son." Kosta becomes postmodern when he realizes that, apart from being a "wooden father", he is also "a wooden son", a sign that had been always understood as pointing towards a concrete past referent, his mother, when that referent had been always absent (or postponed, in Derridean terms). The possible referential relationships that could connect the characters in the story are completely denaturalized, undermined as artificially constructed. As signs, as representations of reality, they find themselves in a Derridean always-retracing search for their original referent, for a transcendental signified that can never be traced. They do not refer to Reality any longer, but to a reality, their own reality.

In this world of simulacra, nobody has a solid past that may contribute to their ascertaining the meaning of their progression in time by means of orientating and teleological referential interconnections. On the contrary, the disintegration of fixed correspondences between sign and referent is made clear when, once Kosta knows his real situation, he sees everybody as if they had turned into ghosts: "I look at him [Adoni] as if he is a ghost. I notice that Anna [Kosta's wife] is standing in the doorway. She too looks like a ghost and she is looking at me as if I am a ghost" (p. 135; my emphasis). They are only shadows in the sense in which the Greek philosopher Plato talks about them in The Republic, but with the difference that this philosopher's shadows were directly projected from their originals, whereas in Kosta's case, as a postmodernist now, that original is not recoverable. All he can say is: "two of those heads the Turks lopped off in Smyrna, two of them belonged to my father and mother" (p. 135). Kosta has learned, borrowing Jean Baudrillard's words, that "[i]n simulation, the metalinguistic illusion duplicates and completes the referential illusion (pathetic hallucination of the sign and pathetic hallucination of the real)" (p. 187). This implies that, once the hallucinatory roles that all of them carry out have been de-familiarized, they have become conscious of the emptiness of their selves, or of the fact that, in our postmodern times, "as individuals, we now occupy 'roles' rather than 'selves'" (Waugh, 1984: 3).

The words that close the story are Kosta's cry "Aiee! I don't like the way the world's going" (p. 135), which, apart from conveying the character's painful transition from modernist to postmodernist, exerts a curious effect in the development of the narrative when one remembers that this same complaint also appears at the beginning of the story (p. 124). This seems to highlight how the narrative follows a circular pattern, which, in the end, is best seen as being spiral. Working back from the end to the beginning, the reader realizes that what had been approached as a simultaneous narration (where Kosta was afraid of the imminent confession that was going to take place) was, in fact, an ulterior one, since everything has already happened when Kosta begins to speak on the first page. The ambiguity that playing with the level of the time of narration creates can be observed, for instance, when Kosta says: "What a shameful thing for a man to live thirty-five years not knowing that his parents are not his parents at all. But what a worst shame for a man to have to be told" (p. 126). At this early stage, the reader in a first approach understands that Kosta is referring to Adoni. However, once the final revelation occurs, the meaning of these 
sentences is enriched, for in the second one Kosta may also be referring to himself. Thab Hassan suggests the opposition between "Distance" and "Participation" (p. 91), among many others, in trying to define the modernist and the postmodernist attitude, respectively. Not being conscious in a first reading of the way in which Swift is playing with this kind of ambiguity, we had been led to think and read as modernists, from the privileged, detached, and relatively safe position that Kosta (as a logocentric humanist still confident of the existence of a transcendental signified) was supposed to be enjoying. Nevertheless, now we understand that we have been reading the story in the wrong manner, or, at least, not in terms of its overall dimensions. We simply had not been tuned in to the postmodern frequency, while, ironically, Kosta had been from the very beginning of his narrative, his Einsteinian claim that "[e]verything changes" being truly postmodern.

It would seem, then, that Swift is making his readers suffer the same transition as Kosta did from a modernist to a postmodernist understanding of life and of reality. Only while rereading the story do we see all of it within postmodern parameters that make the movement not circular, but rather spiral, for we come back to the same story, but with a foreknowledge that, paradoxically, makes our perspective quite different. Now we realize that Kosta has been seeing himself as a complete simulacrum, just as Adoni. He, as "the 'I' which approaches the text" (in this case his life read as such) has understood that he is "a plurality of other texts, of codes which are infinite or, more precisely, lost" (Barthes, 1970:10). Read as signifiers, Kosta and Adoni see themselves obliged to become their own signifieds. As in the case of many metafictional texts, they "have become a nonrepresentational experience, operating within their own closed systems." They are "no longer employed to serve as a medium for transporting semantic messages, instead they thematise themselves. They are no longer used to serve a purpose, they have been depragmatised and are presented as themselves" (Imhof, 1986: 18, 28).

Swift sets forth the first moments of the transition towards postmodernism as a kind of Greek tragedy, for the concept of sparagmos ("the ritual sundering of the body" (Detweiler 1993: 60)) is present overtly and covertly throughout the story. The most explicit example of this appears in the several references that Kosta makes to the time when he cut his mother's (his supposed mother's) fingers. These crude descriptions are quite significant, for they symbolize another kind of severance, namely that of the referential relationship that never existed between them as signs and referents of one another. As Robert Detweiler explains, "[t]he concept of tragedy, beginning with Aristotle, has been intellectualised to the point that what happens to the body is seen to serve mainly as a metaphor for the distress of mind and spirit" (p. 64). Curiously enough, Kosta comes to believe in the end that his real parents were beheaded (p. 135), a graphic and tragic image that again hints at his internal situation as a text made up of absent, irrecoverable intertexts.

Notwithstanding the seemingly tragic implications that sparagmos conveys to the story, this sundering brings connotations of a subsequent liberation. Adopting Roland Barthes's terminology, Kosta (and his life understood as a text) has turned from functioning as a Work to operating as a Text. For Barthes, "the work is concrete", while "the Text ... is a methodological field." The Work implies "the civilization of the Sign" (Kosta's modernist 
stance), and the Text "practices the infinite deferral of the signified" (his postmodernist position). Thus, "[w]hereas the Text is approached and experienced in relation to the sign, the work closes itself on a signified" ("From Work to Text" 74, 76, 75, 76). While Kosta was insisting on reading his life and situation as a Work, he felt his self and Adoni's as being dependent on local and temporal referentiality in order to become meaningful. The necessity of this kind of mainstay did not allow him to admit the relationship between them as acceptable, and he kept on seeing Adoni as a "wooden son." Once he finds out that he is another "wooden son", a text that becomes a complete sign in itself, since it is made up of a signifier that by means of a feedback process of deferral turns into its own signified, he realizes that everybody is a ghost. This understanding develops into a liberating process, as long as he learns that our apprehension of reality always works in that same manner. Since signs do not depend on referential relationships to become meaningful, it might be the case that nobody had the necessity of being anybody else's real son. In a postmodern world, everybody is a "wooden son" and a "wooden father", and "[t]he Text is read without the father's signature" (Barthes, 1971: 78). The author, Barthes explains, "becomes a "paper author'" (1971: 78), and in The Son the real parents-authors, who would determine the characters' lives as following a linear development, have been killed at war and, therefore, obliterated.

As Hartwig Isernhagen puts it, "to search for a more authentic perception of reality, as well as for more authentic ways of verbalizing it, only makes sense if there is a wellgrounded and well-developed notion and experience of alienation and inauthenticity" (pp. 27-28). Kosta has had to overcome this process of detachment and de-familiarization to realize that he cannot affront reality in modernist excluding terms of either or (being or not being Adoni's father) any more, as this would turn him (borrowing T. S. Eliot's famous words in The Waste Land) into "a heap of broken images" that could never be assembled again. For Isernhagen, "[i]f one of the besetting problems of modernism is the fragmentation and partialization of modern life, then the modernist work of art presumes to heal that deficiency (absence) through the creative act. It sets itself up, in face of destruction, as a form of construction; but thereby it does not overcome the lack or solve the problem" (p. 19). Kosta cannot go on understanding that the existence of a real referential relationship between him and his "wooden son" is indispensable for his life to make sense, for him to be a meaningful sign. This is why he eventually adopts a postmodernist inclusive position of both and, according to which he both is and is not Adoni's father, and Adoni is and is not his son. With this, he takes advantage of his plural character once he has finally approached himself as a text.

The changes that Kosta has suffered as a sign throughout the story can be summarized using Roland Barthes's concepts and terminology in his "The Imagination of the Sign." According to this critic, "[e]very sign includes or implies three relations. To start with, an interior relation which unites its signifier to its signified [symbolic]; then two exterior relations: a virtual one that unites the sign to a specific reservoir of other signs it may be drawn from [paradigmatic] ... and an actual one that unites the sign to other signs in the discourse preceding or succeeding it [syntagmatic]" (p. 86). The symbolic relation occurs 
at the beginning of the story, when Kosta describes how he cut off his mother's fingers. At this stage, there seems to be a true internal relationship between Kosta as signifier and his mother as signified. Later on we find that most of the story deals with the description of the problems that the paradigmatic relation of Adoni with Kosta's desired real son who was never born brings about. In this second step the symbolic relation has been obliterated. But there is still a third step when Kosta finds himself in the same circumstances as Adoni. Now Kosta cannot but acknowledge that, in fact, meaning results from "an arrangement of mobile substitutive parts, whose combination produces meaning, or more generally a new object" (Barthes, 1987: 89). Here is where the syntagmatic relation, the one that "renounces the signified", appears to convey a "more structural consciousness than a semantic one" (Barthes, 1987: 88). Thus, at the end of the story, the words "father" and "son" imply a structural and functional, but not a truly semantic consciousness. They only help to create and maintain a structure (in this case, father-son) that does not have the inherent meaning it is assumed to convey. The characters in The Son are fathers, sons, and mothers as long as they combine their roles in such a way that they create the illusion (maybe a possible translation for meaning in postmodernism) of that referential correspondence. As Barthes puts it, "[t]he sign is not only the object of a particular knowledge, but also the object of $a$ vision" (1987: 88; my emphasis).

The key change in Kosta, considered as a sign, is the transition from a paradigmatic to a syntagmatic relation, or, in other words, from a modernist to a postmodernist awareness of man's role in the construction of reality. In fact, the opposition between "Paradigm" and "Syntagm" is also proposed by Hassan to define some differences between modernism and postmodernism (p. 91). In a world where meaning is established through syntagmatic relations, everybody turns into a liar. Thus, Kosta, ironically, yells "to this 'son' I've lied to all my life:" "Elias Tsobanidis is an old liar!" (p. 135). There is, however, a slight difference between modernism and postmodernism in this regard: in the former there are semi-conscious covert liars, whereas in the latter they are conscious and overt ones. It is not until postmodern times that nobody is afraid of supporting B. S. Johnson's assertion that "[t]elling stories really is telling lies" (p. 153), or Thomas Pynchon's when he says that "[i]t is the 'role' of the poet, this 20th Century. To lie" (p. 326). Reality is constantly defamiliarized in postmodernist texts, as also occurs in modernist ones. However, in postmodernism conventions are insistently undermined, and lies exposed, not to eradicate a reality that is seen as artificially constructed, but to install it again with this new and liberating awareness.

So, in "The Son", the main difference between modernism and postmodernism is the overt and explicit acknowledgement of the gulf that exists between a supposedly-existent external and objective reality and our always limited and subjective perception/creation of it. This explains Kosta's following comment: "We're all ghosts. But at the same time I know, I see it as plain as anything -we're all going to carry on just as before, performing our rituals in the restaurant as if nothing has changed, pretending we're people we're not" (p. 135). While many things have changed, everything stays the same, and this is maybe part of the postmodern paradox. At least, this explains why critics find it so difficult to define 
clear boundaries between modernism and postmodernism, since the situation is basically the same, only with the difference that man is much more aware of, and does not mind acknowledging, his really restricted situation. From a postmodern perspective, as Katherine Hayles explains, "[d] enatured language [and reality] is language regarded as ground painted under our feet while we hang suspended in a void. We cannot dispense with the illusion of ground, because we need a place from which to speak. But it is bracketed by our knowledge that it is only a painting, not natural ground" (p. 269). Postmodernist writers, Graham Swift among them, know that they cannot help being liars, but they do not try to conceal it. On the contrary, they have found quite a fertile and creative ground in the undermining or defamiliarization of any position that, in a sense, claims not to be telling a lie. As Swift explains in Waterland, history and reality are no more than stories that once became truth and that are now exposed as stories once more: "First it was a story -what our parents told us, at bedtime. Then it becomes real... Then it becomes a story again" (p. 328).

Summing up, Graham Swift presents what I have called the further step in the defamiliarizing transition from modernism to postmodernism as an initially tragic and painful change. This is why Kosta utters his lament at the end of the story, as a new-born baby that feels that the umbilical cord that kept him linked to his mother, to his origins, has been cut forever. Nonetheless, this first rite of passage is the prerequisite for a new kind of independent, liberated life. Paying attention to the way in which The Son is devised with regard to the time of narration, one realizes that, since the last words send the reader back to the beginning for a reconsideration of the whole text, the opening lines can be as good a conclusion as Kosta's final cry. In this manner, the final catharsis (understood as purgation or clarification) that Kosta, and also the reader, experiences consists in learning and accepting that "[e]verything changes. What you think you know, you don't know. What's good or bad at one time isn't good or bad at another" (p. 124). Swift, apart from defining man as "the story-telling animal", also describes him as "the animal who craves meaning" (Waterland, p. 62, 140), but meaning, as he takes so much trouble to convey in "The Son", and in all his work, is quite elusive and anything but constant and definitive.

Postmodernism's ever-changing, yet constant, spiralling progress is clearly exemplified by the way in which The Son avoids a circular and oppressive reading that would come back time and again to the same modernist master discourse. Postmodernism invites a spiral liberating backwards movement to revisit previous texts, periods, history, etc., with a defamiliarizing intention that helps to take another step forward. This kind of paradoxical movement is at the core of the postmodern concept of history, as Tom Crick, the history teacher in Waterland, makes clear: "[History] goes in two directions at once. It goes backwards as it goes forwards" (p. 135). This contemporary tendency is not an attempt to negate the cliché that There is nothing new under the sun, but, on the contrary it supports it. What postmodernism tries to emphasize is that it is the perceivers that change, for they are textual selves made up, in their turn, of an infinite number of texts that interact to create meaningful apprehensions. Everything stays the same, but people have a different awareness of the way in which reality is man-made, a realization that both Kosta and Adoni have to experience. From this it follows that identities are no more than roles. In Swift's The 
Sweet-Shop Owner (1980), Willy Chapman, the protagonist, states near the end of the novel: "Best to go by the back. Actors slip out by back-exits, leaving their roles on the stage" (p. 215). However, he finally realizes that he cannot take off the mask that he has always worn. He has become the character that he has been impersonating all his life and his identity does not exist unless it is filled up with this role. This is also what happens to Kosta, as he himself understands when he resignedly says: "I will have to pretend once again I'm Zorba the Greek" (p. 132).

The problematic and artificial parent-child correspondences displayed in "The Son", and their recurrence in his novels and short stories, prove Swift's interest in the contemporary situation, where post-structuralist and deconstructionist theories have shaken the basis of any concept of direct referentiality that modernist thinkers might still be interested in reasserting, and where signs are acknowledged to maintain a mere syntagmatic relation among themselves. This interest in discontinuity and in de-familiarizing techniques that may "lay bare the device", the way in which reality is constructed, is plainly revealed in "The Son", where such techniques are foregrounded thereby becoming the main subject of discussion.

\section{Notes}

1. Taking this thematization into account, the word "defamiliarization" acquires a new connotation, for it is understood not only in its literary sense of ostranenie, but also in its more literal one of breaking family bonds or relationships. Whereas both meanings are closely related and interdependent in this study, I will use "defamiliarization" when I emphasize Shklovsky's concept and de-familiarization when, apart from referring to the previous meaning, I stress the second connotation.

2. At this stage I am using the terms sign, signifier, signified, and referent with their Saussurian, structuralist, and semiotic implications in mind, but I will soon turn to their poststructuralist and deconstructionist developments, as Barthes and Derrida understand them. The evolution from structuralist to post-structuralist considerations of these concepts can be mainly appreciated through the figure of Kosta Alexopoulos and the development of his way of approaching and understanding reality. Thus, in a first stage he will think as a traditional logocentric humanist who believes in the existence of a transcendental referent (Derrida's "transcendental signified", and real biological connections in Swift's story) that organizes his personal history and experience; however, he will change his mind when his ultimate referent (his mother) is erased, becoming only a deferred trace in Derridean terms.

\section{Works Cited}

Barthes, Roland (1971): "From Work to Text." Textual Strategies: Perspectives in PostStructuralist Criticism. Ed. Josué V. Harari. London: Methuen \& Co., 1979, 73-81. (1987): "The Imagination of the Sign." Debating Texts: A Reader in Twentieth-Century Literary Theory and Method. Ed. Rick Rylance. Milton Keynes: Open UP, 1987. 86-89. — (1970): S/Z. Trans. Richard Miller. New York: Hill \& Wang, 1974. 
(1970): S/Z. Trans. Richard Miller. New York: Hill \& Wang, 1974.

Baudrillard, Jean (1983): "From The Orders of Simulacra." In Patricia Waugh, ed., Postmodernism: A Reader. New York: Routledge, 1992, 186-188.

Detweiler, Robert (1993): "Torn by Desire: Sparagmos in Greek Tragedy and Recent Fiction."

In David Jasper, ed., Postmodernism, Literature and the Future of Theology. London: Macmillan, 60-77.

Ferraris, Maurizio (1992): "Postmodernism and the Deconstruction of Modernism." In Marco

Diani, ed., The Immaterial Society: Design, Culture, and Technology in the Postmodern

World. New Jersey: Prentice Hall, 13-25.

Fokkema, Douwe (1984): Literary History, Modernism, and Postmodernism. Amsterdam: John Benjamins.

Hassan, Ihab (1987): The Postmodern Turn: Essays in Postmodern Theory and Culture. Ohio: Ohio State UP.

Hayles, N. Katherine (1990): Chaos Bound: Orderly Disorder in Contemporary Literature and Science. Ithaca: Cornell UP.

Hodgson, Peter (1985): "Viktor Shklovsky and the Formalist Legacy: Imitation/Stylization in

Narrative Fiction." In Robert L. Jackson and Stephen Rudy, eds., Russian Formalism: A

Retrospective Glance. New Haven: Yale Center for International and Area Studies, 195-212.

Holquist, Michael (1985): "Bakhtin and the Formalists: History as Dialogue." In Robert L. Jackson and Stephen Rudy, eds., Russian Formalism: A Retrospective Glance. New Haven: Yale Center for International and Area Studies, 82-95.

Hutcheon, Linda (1988): A Poetics of Postmodernism: History, Theory, Fiction. New York: Routledge.

Imhof, Rüdiger (1986): Contemporary Metafiction: A Poetological Study of Metafiction in English since 1939. Heidelberg: Carl Winter.

Isernhagen, Hartig (1986): "Modernism/Postmodernism: Continuities of a 'Split Repertoire of

Narrative Themes and Strategies (A Provisional Restatement of a Traditional View of Twentieth Century Literary Avant-gardism)." In Marc Chénetier, ed., Critical Angles: European Views of Contemporary American Literature. Carbondale: Southern Illinois UP, 15-28.

Jakobson, Roman (1971): "The Dominant." In Ladislav Matejka and Krystina Pomorska, eds., Readings in Russian Poetics: Formalist and Structuralist Views. Cambridge: MIT Press, 105-110.

Johnson, B. S. (1973): "Introduction to Aren't You Rather Young To Be Writing Your Memoirs?"

In Malcolm Bradbury, ed., The Novel Today: Contemporary Writers on Modern Fiction. Manchester: Manchester UP, 1977. 151-168.

Lethen, Helmut (1986): "Modernism Cut in Half: The Exclusion of the Avant-garde and the Debate on Postmodernism." In Douwe Fokkema and Hans Bertens, eds., Approaching Postmodernism. Amsterdam: John Benjamins, 233-238.

Lodge, David (1977): The Modes of Modern Writing: Metaphor, Metonymy, and the Typology of Modern Literature. Ithaca: Cornell UP.

McHale, Brian (1987): Postmodernist Fiction. New York: Methuen.

Pynchon, Thomas. V. (1963): New York: Harper \& Row, 1986.

Swift, Graham (1982): "The Son." In Learning to Swim and Other Stories. New York: Vintage, 124-135. 
(1980): The Sweet-Shop Owner. New York: Vintage, 1993.

(1983): Waterland. London: Picador, 1992.

Waugh, Patricia (1984): Metafiction: The Theory and Practice of Self-Conscious Fiction. New York: Methuen.

Wilde, Alan (1987): "From Modernism and the Aesthetics of Crisis." In Patricia Waugh, ed., Postmodernism: A Reader. New York: Routledge, 1992, 14-21. 